tions after the consumption of different carbohydrate foods has been emphasised as the insulin responses can vary considerably even when glucose responses are similar and might be of more clinical significance in the non-diabetic population. ${ }^{14}$ In our study the sustained high insulin concentration after salted bread was probably responsible for the steep drop in plasma glucose concentration after 30 minutes (fig 2). Our findings of the small rise in plasma glucose concentration after the consumption of lentils and the fall below fasting concentrations (fig 1) have been seen after the consumption of other test meals of lentils and soya beans. ${ }^{20}$

The findings of this preliminary study, if confirmed by others, including those of diabetics, would support the recommendation that diabetics, ${ }^{21.23}$ as well as the general population, ${ }^{2+26}$ should reduce their intake of salt. The differences seen after the consumption of unsalted and salted foods justify a controlled trial of the use of salt restriction in a group of stable diabetic patients as an additional way to lower postprandial plasma glucose concentrations.

This work was supported by the Sydney University Nutrition Research Foundation. We thank Professor G Berry, School of Public Health and Tropical Medicine, University of Sydney, for statistical advice.

\section{References}

1 Jenkins DJA, Wolever TMS, Taylor RH, et al. Glycemic index of foods: a physiological basis for carbohydrate exchange. Am $\mathcal{F}$ Clin Nutr 1981;34:362-6.

2 Ionescu-Tirgoviste C, Popa E, Sintu E, Mihalache N, Cheta D, Mincu I. Blood glucose and plasma insulin responses to various carbohydrates in Tvpe 2 (non-insulin-dependent) diabetes. Diabetologia 1983;24:80-4

3 Jenkins DJA, W'olever TMS, Jenkins AL, Josse RG, Wong GS. The glycaemic response to carbohvdrate foods. Lancet 1984;ii:388-91

4 Jenkins DJA, Wolever TMS, Leeds AR, et al. Dietary fibres, fibre analogues, and glucose tolerance: importance of viscosity. BrMed f 1978;i:1392-4.

Yoon JH, Thompson LU, Jenkins DJA. The effect of phytic acid on in vitro rate of starch digestibility and blood glucose response. Am f Clin Nutr 1983;38:835-42.
6 Anderson IH, Levine AS, Levitt MD. Incomplete absorption of the carbohydrate in all-purpose wheat flour. N Engl f Med 1981;304:891-2.

Goddard MS, Young G, Marcus R. The effect of amylose content on insulin and glucose responses to ingested rice. Am f Clin Nutr 1984;39:388-92.

Snow P, O'Dea K. Factors affecting the rate of hydrolysis of starch in food. Am $\mathcal{f}$ Clin Nutr 1981;34:2721-7.

9 Brand JC, Nicholson PL, Thorburn AW, Truswell AS. Food processing and the glycemic index. Am f Clin Nutr 1985;42:1192-6.

10 Jenkins DJA. Lente carbohydrate: a newer approach to the dietary management of diabetes. Diabetes Care 1982;5:634-41.

11 Southgate DAT. Determination of carbohydrate in foods. 1-Available carbohydrate. $\mathcal{F}$ Sci Food Aric 1969;20:326-35. 12 Clegg KM. The application of the anthrone reagent to the estimation of starch in cereals. $\mathcal{F} S c i$

13 Fregly MJ. Sodium and potassium. In: Olsen RE, ed. Nutrition reviews' present knowledge in nutrition. Washington, DC: The Nutrition Foundation, 1984:439-58.

4 Clifford WM. The effect of halogen salts on salivary and pancreatic amylase. Biochem $\mathcal{J}$ 1936;30:2049-53.

15 Vander AJ, Sherman JH, Luciano DS. Digestion and absorption of food. In: Adams TAP, First C, eds. Human physiology-the mechanisms of body function. New York: McGraw-Hill, 1975:355-91.

16 Dawes $\mathrm{C}$, Jenkins GN. The effects of different stimuli on the composition of saliva in man I Physiol 1964;170:86-100.

17 Gray GM. Carbohydrate digestion and absorption. Role of the small intestine. $N$ Engl 7 Med $1975 \cdot 292: 1225 \cdot 30$

18 Favin MN, McMurty ME. Oral rehydration therapy. Geneva: World Federation of Public Health Associations, 1983 .

19 Coulston AM, Hollenbeck CB, Reaven GM. Utility of studies measuring glucose and insulin responses to various carbohydrate-containing foods. Am f Clin Nutr 1984;39:163-5.

20 Jenkins DJA, Wolever TMS, Taylor RH, et al. Rate of digestion of foods and postprandial Jenkins DJA, Wolever TMS, Taylor RH, et al. Rate of digestion of
glycaemia in normal and diabetic subjects. Br Med f 1980;281:14-7.

21 Nutrition Sub-Committee of the British Diabetic Association's Medical Advisory Committee. Dietary recommendations for diabetics for the 1980 s - a policy statement by the British Diabetic Association. Hum Nutr Appl Nutr 1982;36A:378-94.

22 American Diabetes Association. The American Dietetic Association. Family cookbook. Eaglewood Cliffs, New Jersey: Prentice Hall, 1984;2:8-9.

23 Huttunen JK, Aro A, Pelkonen R, Puomio M, Siltanen I, Ákerblom HK. Dietary therapy in diabetes mellitus. Description of a recommendation prepared by the Finnish Diabetes Association's committee on nutrition therapy. Acta Med Scand 1982;211:469-75.

24 National Advisory Committee on Nutrition Education. A discussion paper on proposals for nutritional guidelines for heallh education in Britain. London: HMSO, 1983.

25 Truswell AS. The development of dietary guidelines. Food Technology in Australia 1983;35: 498-502.

26 McNutt K. Dietary advice to the public: 1957-1980. Nutr Rev 1980;38:358-60.

Accepted 10 April 1986

\title{
Assessment of oral candidiasis in patients with respiratory disease and efficacy of a new nystatin formulation
}

\author{
P J THOMPSON, H J WINGFIELD, R F COSGROVE, B O HUGHES, \\ $M$ E TURNER-WARWICK
}

\begin{abstract}
Fifty consecutive patients with respiratory diseases who developed oropharyngeal candidiasis were assessed clinically and microbiologically before and after seven days' treatment with nystatin suspension or pastilles (a new formulation). In 45 patients in whom microbiology yielded positive results there was frequent associated use of oral corticosteroids, antibiotics, sedatives, and inhaled corticosteroid, while in a few patients atropine analogues may have predisposed to infection. Dentures were worn by 32 of the infected patients. Concomitant treatment of dentures in chronically infected patients appeared to improve
\end{abstract}

Professorial Unit, Department of Medicine, Cardiothoracic Institute, London P J THOMPSON, FRACP, lecturer

ME TURNER-WARWICK, PHD, FRCP, professor

Brompton Hospital, London

H J WINGFIELD, chief medical laboratory scientific officer, microbiology department

B O HUGHES, principal pharmacist, pharmacy department

The Squibb Institute for Medical Research, Moreton, Wirral, Merseyside R F Cosgrove

Correspondence to: Dr P J Thompson, University Department of Medicine, Queen Elizabeth II Medical Centre, Nedlands 6009, Western Australia. the therapeutic response. Pastilles and suspension were equally efficacious both clinically and microbiologically.

The potential for enhanced drug delivery to the oropharynx suggests that nystatin pastilles may be useful in patients in whom poor compliance seems likely.

\section{Introduction}

Oral candidiasis is common in patients with respiratory disease and predisposing states have been described. ${ }^{1}$ Despite repeated treatment chronic infection occurs, and nystatin pessaries have therefore been prescribed to achieve greater contact time between drug and oropharynx..$^{23}$ Pessaries have an unpleasant taste, however, so that compliance with treatment may be poor. To overcome these problems a pastille of nystatin has been formulated. We have assessed its clinical efficacy and carried out a clinical audit of 50 patients with respiratory diseases who developed oral candidiasis.

\section{Patients and methods}

After removing antifungal agents from the wards we investigated 50 consecutive patients who had been prescribed this treatment. All were questioned about symptoms, primary chest disease, and current drug treatment. Other predisposing factors such as diabetes, malignancy, recent infection, and dentures were recorded.' Chronic infection was defined as four or more infections in the past 12 months. Six clinical signs of oral 
candidiasis ${ }^{1}$ were scored 0 to 3 and summed. Mouth swabs were taken at predetermined sites and cultured on Sabouraud glucose peptone agar. Direct microscopy and a colony forming unit count (after three days' incubation at $37^{\circ} \mathrm{C}$ ) were performed.

Patients were allocated at random to receive pastilles or suspension (nystatin 100000 units) four times a day for seven days; no food or drink was taken for one hour after dosing. Dentures were soaked in $0.5 \%$ chlorhexidine and alcohol each night.

Patients kept a diary card comparing symptoms with the previous day (scoring -3 to +3 ) and a weekly score quantifying degree and rate of improvement was derived: daily scores were multiplied by the reciprocal of the day of scoring and summed. At end of treatment patients were reassessed clinically and microbiologically with the assessor blind to treatment. Patients provided scores ( 0 to 3 ) for palatability and acceptability.

Brompton Hospital's ethics committee approved the study and all patients gave informed consent. Statistical comparison between treatments was assessed by Student's paired and unpaired $t$ tests.

\section{Results}

Twenty four men and 21 women aged $18-80$ (mean age 59) had positive cultures. Table I lists their primary diagnoses and frequency of predisposing conditions. A large proportion wore dentures or had been prescribed oral corticosteroids, antibiotics, and sedatives. Five used atropine analogues or had Sjögren's syndrome.

Forty of the 45 patients had symptoms. Thirty eight complained of a painful mouth, 13 a husky voice, seven pain on swallowing, and two a painful tongue. All 45 had abnormal physical findings, including 40 with white plaques, 36 with glossitis, and four raw oral mucosa alone.

Of the 45,22 patients were given the pastilles and 23 the suspension. Nine died or defaulted, however, leaving 18 in each treatment group. For mean diary card scores and improvement in clinical signs and microbiological accounts (table II) there was no significant difference between formulations. The score for mean clinical signs improved by $87 \%(\mathrm{p}<0.001)$ for pastilles and $80 \%(\mathrm{p}<0.001)$ for suspension. A statistically significant $(\mathrm{p}<0.001)$ reduction in mean colony forming counts for pastilles (123 colonies; SEM 22) and for suspension (124; SEM 22) occurred. The treatments were equally palatable and acceptable (table II).

All eight patients with chronic infection has significant improvement after treatment (five given pastilles, three suspension). Five had failed with all other treatments, this being their best response.

The five patients with negative initial cultures all had clinical signs with mean scores of $6 \cdot 1$ (SEM 1.4) before treatment and 1.7 (SEM 0.4) after treatment. The mean score for improvement in symptoms was $1 \cdot 3$ (SEM $0 \cdot 5)$.

TABLE I-Primary diagnosis and possible predisposing conditions to candidal infection in 45 sequential patients with microbiologically confirmed oropharyngeal candidiasis

\begin{tabular}{lclc}
\hline \multicolumn{1}{c}{$\begin{array}{c}\text { Primary } \\
\text { diagnosis }\end{array}$} & $\begin{array}{c}\text { No of } \\
\text { patients }\end{array}$ & \multicolumn{1}{c}{$\begin{array}{c}\text { Predisposing } \\
\text { condition }\end{array}$} & $\begin{array}{c}\text { No of } \\
\text { patients }\end{array}$ \\
\hline $\begin{array}{l}\text { Carcinoma } \\
\begin{array}{l}\text { Chronic airways obstruction } \\
\text { (including asthma) }\end{array}\end{array}$ & 18 & $\begin{array}{l}\text { Dentures } \\
\text { Oral corticosteroids }\end{array}$ & 32 \\
$\begin{array}{l}\text { Pneumonias and lung infections } \\
\text { Fibrosing alveolitis }\end{array}$ & 13 & $\begin{array}{l}\text { Antibiotics } \\
\text { Tranquillisers/narcotics }\end{array}$ & 27 \\
Cystic fibrosis & 3 & Inhaled corticosteroids & 25 \\
Others & 2 & Recent chest infections & 17 \\
& 5 & $\begin{array}{l}\text { Atropine/Sjogren's syndrome } \\
\text { Radiotherapy }\end{array}$ & 5 \\
& & Diabetes & 5 \\
& & Cancer chemotherapy & 5 \\
\end{tabular}

\section{Discussion}

Nystatin, a polyene antifungal agent, is reasonably effective in candidiasis. ${ }^{4}$ Maintaining adequate concentrations in the oropharynx cannot be ensured, however, which may influence success in individual patients. Oral nystatin salivary concentrations are considerably greater for pessaries and pastilles than for suspension (data available on request). In this study, though pastilles and suspension were similarly efficacious, restricting food and drink after dosing may have enhanced the contact time for suspension, reducing detectable differences. Nystatin's bitter taste needs masking to be acceptable but three patients disliked the aniseed flavouring and stopped the treatment. Taste and compliance must be superior to pessary, however, which has no masking at all.
TABLE II-Mean (SE) scores for diary card symptom score, clinical signs score, microbiology colony counts, palatability score, and acceptability score for pastilles and suspension (includes, where relevant, data from patients with negative cultures)

\begin{tabular}{lcc}
\hline & $\begin{array}{c}\text { Pastilles } \\
(\mathbf{n}=16-23)\end{array}$ & $\begin{array}{c}\text { Suspension } \\
(\mathbf{n}=18 \text { or } 19)\end{array}$ \\
\hline Improvement in symptoms (diary card) & $1 \cdot 5(0 \cdot 2)$ & $1 \cdot 5(0 \cdot 3)$ \\
Signs before treatment & $7 \cdot 9 \cdot(0 \cdot 9)$ & $8 \cdot 1(0 \cdot 9)$ \\
Signs after treatment & $1 \cdot 0(0 \cdot 3)^{\star}$ & $1 \cdot 6(0 \cdot 7)^{\star}$ \\
Colony forming unit count before treatment & $151 \cdot 0(19 \cdot 0)$ & $162 \cdot 0(17 \cdot 0)$ \\
Colony forming unit count after treatment & $28 \cdot 0(17 \cdot 0)^{\star}$ & $38 \cdot 0(18 \cdot 0)^{\star}$ \\
Palatability & $2 \cdot 5(0 \cdot 1)$ & $2 \cdot 2(0 \cdot 2)$ \\
Acceptability & $2 \cdot 6(0 \cdot 1)$ & $2 \cdot 4(0 \cdot 2)$ \\
\hline
\end{tabular}

*Compared with pretreatment value: $\mathrm{p}<0.001$.

Analysis of associated conditions confirmed the important association between dentures and infection..$^{5}$ Dentures cause tissue trauma, provide sites for colonisation, and diminish salivary flow. ${ }^{\prime}$ Saliva is thought to be necessary for normal oral immune defences, ${ }^{6}$ and five of our patients had poor salivary flow due to anticholinergic treatment or Sjögren's syndrome. Though Sjögren's syndrome is associated with increased infection,' the contribution of atropine analogues has not been reported.

Inhaled corticosteroids predispose to infection ${ }^{8}$ but in our patients antibiotics and oral corticosteroids were more commonly associated, and there are several mechanisms for this association. ${ }^{\prime}$ Use of sedatives (including narcotics) was similarly frequent, and presumably lack of denture cleaning and diminished food intake reducing salivary flow contributed.

Although medical treatment has been influenced little by dentists' concern about dentures, beneficial responses in the eight patients with chronic infection may have been due to chlorhexidine treatment of dentures. None had tried this treatment before, nor been instructed to refrain from eating or drinking after treatment. These manoeuvres may have been critical in obtaining a superior response.

Difficulty in diagnosis occurred in a few patients with symptoms, signs, and microbiological findings showing a lack of correlation. Improvement in microbiologically negative patients given nystatin suggests that antibiotics or other organisms may have inhibited culture. Microbiology remains useful when clinical signs are atypical, and inspection of the oropharynx in patients with predisposing states is recommended.

Patients with respiratory diseases entered into this study were sequentially diagnosed as having oral candidiasis. The distribution of likely predisposing factors among this sample highlights the importance of dentures, antibiotics, steroids, and sedation and suggests that atropine analogues may also be relevant. Of greater importance, however, was the success of nystatin when supported by chlorhexidine treatment of dentures and measures enhancing retention of drug in the oropharynx. Clinically the pastille formulation was as effective as suspension and the potential for enhanced drug delivery to the oropharynx suggests that it may be additionally beneficial for patients in whom poor compliance with therapeutic instructions seems likely.

We thank Mr P Woods, of E R Squibb and Sons Ltd, for his help and Dr J Kirk and Dr R Prince for editorial work.

\section{References}

1 Odds FC. Candida and candidosis. Leicester: Leicester University Press, 1979:75-100. 2 Mansour A, Gelfand EW. A new approach to the use of antifungal agents in infants with persistent oral candidiasis. F Pediatr 1981;98:161-2.

3 Lawson RD, Bodey GP. Comparison of clotrimazole trache and nystatin vaginal tablet in the treatment of oropharyngeal candidiasis. Current Therapeutic Research 1980;27:774-9.

4 Cohen L. Oral candidosis-its diagnosis and treatment. 7 Oral Med 1972;27:1-22.

5 Arendorf TM, Walker DM. Oral candidial populations in health and disease. Br Dent $\mathcal{F}$ 1979;147:267-72.

6 Budtz-Jorgenson E. Oral mucosal lesions associated with the wearing of removable dentures. 7 Oral Pathol 1981;10:65-80.

7 Tapper-Jones L, Aldred M, Walker DM. Prevalence and intraoral distribution of Candida albicans in Sjögren's syndrome. F Clin Pathol 1980;33:282-7.

8 Willey RF, Milne LJR, Compton GK, Grant IWB. Beclomethasone dipropionate aerosol and oropharyngeal candidiasis. Br 7 Dis Chest 1976;70:32-8.

(Accepted 10 April 1986) 